\title{
Expanding the Frontier in Education Research: Teacher Education Could Help Promote Activities That Affect Students' Ability to Learn in the Long-Run
}

\author{
Philippe C. Baveye* \\ AgroParisTech, Université Paris-Saclay, Thiverval-Grignon, France
}

Keywords: active learning, self-directed learning (SDL), critical thinking abilities, team work, lifelong learning

\section{OPEN ACCESS}

Edited by:

Luiz Sanches Neto,

Universidade Federal do Ceará, Brazil

Reviewed by:

Vânia Galindo Massabni,

University of São Paulo, Brazil

*Correspondence:

Philippe C. Baveye

philippe.baveye@agroparistech.fr

Specialty section

This article was submitted to

Teacher Education,

a section of the journal

Frontiers in Education

Received: 24 September 2018 Accepted: 27 December 2018 Published: 23 January 2019

Citation:

Baveye PC (2019) Expanding the Frontier in Education Research: Teacher Education Could Help Promote Activities That Affect Students' Ability to Learn in the Long-Run. Front. Educ. 3:120. doi: 10.3389/feduc.2018.00120
The very name of this journal, Frontiers in Education, begs the questions of where the "frontiers" should be at present in education research, and how we can ensure that breakthroughs at these frontiers be rapidly put into practice. In this context, this short opinion article argues that in order to answer these two questions adequately, we, educators, should stop zeroing in on the content or skills we want students to have acquired right at the end of a cycle of studies, be it elementary, high school, or university. Instead, we should not be afraid to ask people who are many years, even decades, past formal education what they think we should focus on, where our teaching can be most effective. My own experience with two eye-opening events suggests that from this lifelong perspective, teaching activities that are likely to be most influential over the course of a person's life do not necessarily follow traditional formats. In terms of facilitating implementation of innovative teaching activities, since it seems very arduous to convince schools to add anything to already overloaded curricula, perhaps this is not where we should concentrate our efforts. I argue that the easiest way to implement change may be to first demonstrate practically to future teachers, enrolled in teacher education programs, that even brief learning activities can have enormous merit.

\section{INPUT FROM THE "REAL WORLD”}

If one considers that the objective of high-school and university education is to eventually equip students, at the age of 22 or 23, with the "body of knowledge" and skills that are relevant in their field of specialty, then the frontier one needs to consider in research encompasses all the novel approaches currently under development to better achieve this specific objective. Alternatively, one might adopt the perspective that what happens at the end of undergraduate studies is not necessarily that meaningful, given the fact that graduates will generally work for 42 or 43 years afterwards, change jobs a number of times, and end up doing things for which the content and skills acquired during their undergraduate studies may not be relevant at all. In that lifelong context, one could assume that the "frontier" on which our research in education should focus relates to novel activities that would prepare individuals for the constantly changing landscape that they will face all along their life, including, but not exclusively, during their professional career.

One way to get ideas about novel teaching activities we should develop in that latter context consists of simply asking individuals who were in school or at the university 20,30 , or even 40 years ago, to identify the part of their education, taken broadly, that was most valuable to them. The idea is not entirely new, of course, since it was adopted 60 years ago already in the pioneering work of Bertrand Schwartz, in preparation for his landmark reform of the School of Mines in Nancy (France) during the late 1950s (Lambrichs, 2009). Nevertheless, given the strong emphasis in education research on psychometric tests and the application of statistical methods to 
surveys of large cohorts, a perspective centered on individual's opinions is likely to be criticized as "anecdotalist," potentially biased, and not sufficiently rigorous. Fortunately, it is not necessary to simply rely on individual's perceptions, which may indeed be occasionally off if questions are not asked appropriately. Over the last few decades, various educational theorists (e.g., Dominicé, 2000; Dhunpath and Samuel, 2009) have proposed and perfected several techniques to indirectly derive meaningful information about the education of individuals by carefully analyzing biographical stories they may have written. Perhaps, as in the field of self-directed learning (Baveye, 2003), this "life history" approach could help us establish on a firm foundation the expanding frontier(s) in education. This message is clearly conveyed by Goodson and Gill (2014), who argue that "life narratives" can help educators shift from a disenfranchised tradition to one of empowerment.

Of course, clearly, this incorporation of the experience of people "in the real world" into school and university curricula needs to be carried out cautiously. It would not be appropriate for economic and competitive interests of groups outside the school community to sway the educational process in a direction that is not ultimately in the best interest of students. One also needs to be careful not to disenfranchise teachers or weaken their agency and collaboration. Because they are intimately involved in the educational process, any discussion about its evolution in the future absolutely needs to include them directly.

Anyway, in this context of input "from the real world," the question of which activities were most influential in my education has intrigued me a lot over the last two or three decades. Clearly, the answer is not to be found in the formal lectures I attended, since I promptly forgot just about everything I learned from them, except in a few rare instances where I had a strong prior motivation to learn the material, on my own if need be. Even in these few cases, most of the content and skills I learned back then turned out to be obsolete after a decade, and had little influence on my later career in science ${ }^{1}$. Careful reflection suggests that by far the most significant learning experiences of my entire schooling were associated with two very short, active learning events, which perhaps paradoxically, had nothing at all to do with the training I got at the university.

\section{SHORT TEACHABLE MOMENTS...}

The first of these two influential events took place when I was 17, in 1974, many years before Internet or Facebook existed. One of the teachers in my junior year in high school asked our class to attend a politically-motivated street demonstration held during the week end in the nearest big city. The protest was against an exhibition that was organized to promote tourism in a foreign country, which at that time was under a brutal dictatorship. Many non-governmental organizations and citizens' groups were staunchly opposed to the exhibition. The experience of attending the peaceful demonstration, among a

\footnotetext{
${ }^{1} \mathrm{My}$ experience in this respect conforms scrupulously to the conclusion of Gibbon (1776) who wrote that "the power of instruction is seldom of much efficacy, except in those happy dispositions where it is almost superfluous."
}

crowd we estimated to be around 250,000 to 300,000 people, was eye-opening in itself, but what made it unique was what happened in school the following Monday. In the early morning, the teacher had purchased all the local newspapers he could find. He assigned us to read and analyze the different accounts these newspapers provided of the street demonstration. Whereas, left-leaning newspapers reported that upwards of 500,000 people had marched peacefully through the streets, right-wing journals described the demonstration as a small gathering of merely 50,000 people, and commented incorrectly that some of them had become violent. Several newspapers did not report the protest at all. Meanwhile, the police account of the demonstration mentioned an intermediate number of $\sim 200,000$ people. After less than an hour of reviewing the different articles, many of us admitted in the ensuing discussion that we were stunned by what we had found. Even though nowadays "alternate facts" have become common place, at the time none of us anticipated disparities to be so blatant between different newspapers. In hindsight, I feel that in one hour of hands-on, discovery-based exposure to a variety of perspectives on the same event, I learned more about the need for a critical analysis of texts, and for a proper account of the socio-economic and historical context in which texts are written, than in any of the formal courses I took on the subject later on in college. Undoubtedly, my upbringing in a family of intellectuals made me particularly receptive to this kind of teachable moment, and individuals reared in very different environments may not be as fertile ground as I was, but the fact is that I have never looked at the written word after this single exercise as I did before, nor for that matter at anything that lecturers would talk about in the courses I took afterwards (some of which turned out after a little scrutiny to deliver information that was obsolete or even erroneous).

The second event occurred during the Summer just before I started attending the university. My high school had made it possible for a group of students to help with development activities in what was still commonly referred to at the time as the "Third World." Specifically, we were supposed to help missionaries in Rwanda with various practical, mostly agricultural, projects. In the evenings, in the tiny village where we were staying, there was very little to do, except play cardand board games. A favorite activity of the missionaries was to play Scrabble. On one of the first nights I was there, we started a game with them, and basically I played the way my mother had shown me, to try to win by placing words that would earn me more points than what the other players could do with their letters. After a couple of moves, the missionaries stopped the game and told me that this was not how they played it at all. They proceeded to show me how each of them was trying to place words in such a way that all players together would eventually make the most points possible. So instead of proudly putting "taxes" in one move, someone would only put down "ax," then another would add a " $t$," to obtain "tax," then a third could make it "taxes," and finally, someone could add "sur" to come up with "surtaxes." All in all, that means that the points of the very valuable letter " $x$ " would count five times instead of one, increasing the combined score 
of all the players at the end of the game. The details of the Scrabble strategy do not matter that much, but what was really a revelation in what the missionaries showed me is that rules can easily be changed to maximize the benefits, in this case the enjoyment, for all involved. The original rules of Scrabble require individual competition among players, and they invariably lead to one player being happy at the end while all the others are less so, to put it mildly. The lesson I got was that it is easy to transform the game into something that is eminently collaborative, such that everyone feels pretty much the same way at the end, depending on how well the group did. As a result, what could be a divisive pastime, especially if one of the players happens to be unreasonably competitive, becomes an activity that strengthens the cohesion of the group and enhances team spirit $^{2}$.

\section{LONG-LASTING LESSONS LEARNED...}

Over the years, during my subsequent career as a researcher, I have had many occasions to reminisce about these two events. The older I get, the more I realize how extremely significant they were in my education, overshadowing many other aspects of it. As short as it was, the newspapers-related activity singlehandedly shaped my attitude toward the written word. Every single time I now read an article or a book, I remember the fateful Monday when my classmates and I compared multiple newspaper clippings. As a result, I never take any text (or, for that matter, lecture notes) for granted any more, and I am compelled to systematically look for alternative perspectives on the same topics before I formulate my own opinion. This critical attitude toward texts has played a key role in my work, as it has stimulated me not only to keep learning efficiently on my own, as a self-directed learner, from a variety of sources, but also to try to foster self-directed learning in my students (Baveye, 1994). This capacity is particularly crucial in fields in which phenomenal technological breakthroughs occur at very regular intervals, and the need to renew one's knowledge base is constant.

The Scrabble-related experience still stimulates me daily to try to diffuse the intense, oppressive feeling of competition that nowadays pervades the world of scientific research, and to do everything possible to foster instead a genuine collaboration among the various members of the research groups to which I participate. Time and again, I have found that this is the most effective, and humanly satisfying, way to find answers to the research questions we are addressing. This is especially true in research in environmental science, where increasingly the question we need to address require a truly interdisciplinary perspective and teams of researchers with different specialties working together to achieve common goals (see example in Baveye et al., 2018).

\footnotetext{
${ }^{2}$ To my mother's credit, I should mention I found out years later that when, upon retirement, she joined a Scrabble club, she and her friends all played only a collaborative form of Scrabble, which they found to be far more satisfying than the competitive one.
}

\section{OBSTACLES TO IMPLEMENTATION IN THE CURRICULUM}

A priori, it would seem relatively simple to implement one or both of these "teachable moments" described above in middleor high schools, and definitely at the university level. The format of activities that could be proposed to students can be inspired by those described above, but details can be changed at will. Instead of asking students to attend a demonstration in person, with all the logistic, insurance, and security concerns that this may raise, students can be asked to watch a key political speech on television, like the State of the Union address, or any other event that is likely to polarize public opinion. Students can then be asked to retrieve and analyze newspaper articles, as well as blogs or Tweets, dealing with that same speech or event. For the second activity, instead of Scrabble, if it does not appeal to students, one might consider a game like Monopoly. In its usual form, with which many students are likely to be familiar already, the game is far more competitive than Scrabble, its goal being to saddle opponents with debt and eventually reduce them to financial ruin (Ketcham, 2012; Pilon, 2015). But one could suggest to students to slightly change the rules, so that players work together toward increasing everyone's well-being. Instead of paying rent to a property's title holder, players would pay into a common pot, from which it would be possible to later draw.

When I tried to convince teachers to adopt one or both of these exercises in their classes, in one form or another, their reaction, frequently, was that the curriculum is already so full in most schools that it is not feasible to fit anything else in. Given how little time it takes to read a few newspaper articles or to play a game of Scrabble, this objection is easy to counter. Even if teachers do not want to devote regular class time to what they view as "extra-curricular" activities, there is room at various times during the year to hold them. For example, at the end of each term, after exams, middle- and high-school students are traditionally allowed to wind down for a few days. Most schools let the students be idle, and some of them do not even show up any more. If teachers need this "down" time to take care of various yearend administrative duties, schools could use a resource that at the moment often remains largely untapped: Retired individuals who want to remain active could come to schools as guests or visitors for a few hours to lead one of the teaching exercises described above. This would be very welcome, as long as these individuals do not try to promote the viewpoint of a particular economic interest group. At the university level, if instructors feel uncertain about including a game of Scrabble or Monopoly in their curriculum, student organizations can be encouraged to take on these activities separately, with faculty assistance.

Beside the perceived lack of time, a common objection of teachers toward "short teachable moments" has to do with a clear reluctance to accept the idea that an activity that takes only a few hours, and is not repeated multiple times over at least a semester, could have a lasting effect on students. Faced with this perception, I have tried, sometimes with success, most often not, 
to argue that there is a historical precedent showing that this type of short activity can have a tremendous impact. It is the celebrated "Blue eyes, brown eyes" experiment that Jane Elliott carried out over a two-day period in 1968. A PBS documentary about the experiment, titled "A class divided" (still readily accessible on Internet at www.pbs.org/video/frontline-class-divided/) and its companion book (Peters, 1987), show that 14 years after a 1970 repeat of Elliott's original experiment, participants acknowledged that it had been "life-affecting" and had a profound influence on them.

\section{A WAY FORWARD}

The manifest reluctance that I have witnessed whenever I tried to convince teachers in schools and universities to adopt short "teachable-moments" in their classes suggests that at the moment they may not be the right initial audience for this kind of innovative approach to learning. In the short run, the best strategy to promote this approach may be to first target teacher education programs. If we can convince future teachers that with activities that only last a couple of hours, they have the power to change profoundly their student's attitude toward learning or collaborating in teams, chances are that they would try their utmost to schedule such activities in their classrooms when they start teaching. Through their example, the innovation would then likely spread to other teachers, as it appears to be frequently the case in industry, where young recruits, fresh out of school, and the knowledge they bring with them, are key to the adoption of new technologies (e.g., Janssen and Mohrenweiser, 2018). Incidentally, targeting teacher education programs may be a good strategy not only in this specific case, but also more generally

\section{REFERENCES}

Baveye, P. (1994). "Fostering learner self-direction in soil science graduate courses: a new paradigm," in Soil Science Education: Philosophy and Perspectives, eds P. Baveye, W. Farmer and T. (Madison, WI: Logan SSSA Special Publication 37, Soil Science Society of America), 137-178.

Baveye, P. (2003). Refocusing the self-directed learning debate. Fam. Med. 35, 445-446.

Baveye, P. C., Otten, W., Kravchenko, A., Balseiro Romero, M., Beckers, É., Chalhoub, M., et al. (2018). Emergent properties of microbial activity in heterogeneous soil microenvironments: different research approaches are slowly converging, yet major challenges remain. Front. Microbiol. 8:1364. doi: $10.3389 /$ fmicb.2017.01364

Delbanco, A. (2014). College: What it Was, is, and Should Be - Updated Edition. Princeton, NJ: Princeton University Press.

Dhunpath, R., and Samuel, M. (2009). Life History Research: Epistemology, Methodology and Representation. Rotterdam: Sense Publishers.

Dominicé, P. (2000). Learning From Our Lives. San Francisco, CA: Jossey-Bass Publishers.

Gibbon, E. (1776). The History of the Decline and Fall of the Roman Empire, Volume 1. London: Longman, Rees, Orme, Brown, and Green.

Goodson, I., and Gill, S. (2014). Critical Narrative as Pedagogy. New York, NY: Bloomsbury Academic.

Janssen, S., and Mohrenweiser, J. (2018). The Shelf Life of Incumbent Workers During Accelerating Technological Change: Evidence From a Training Regulation Reform. Discussion Paper 11312. IZA-Institute of Labor Economics (Bonn).

Jaschik, S. (2015). Well-Prepared in Their Own Eyes. Inside Higher Ed. Available online at: https://www.insidehighered.com/news/2015/01/20/study-findsbig-gaps-between-student-and-employer-perceptions (Accessed Januray 20, 2015). for the promotion of other innovative approaches to student learning.

In the long run, the adoption of novel learning methods may be greatly facilitated when universities start addressing in earnest the key question of "What is college for?" (Lagemann and Lewis, 2011; Delbanco, 2014; Roth, 2017), in response to potential employers and the public in several countries increasingly commenting that university graduates are not properly equipped to face the challenges of the twenty-first century (e.g., Saavedra and Opfer, 2012; Jaschik, 2015). To answer this criticism, it will become mandatory to look outside the box, and to routinely ask to people "in the real world," including former graduates, what they think students should learn in school, and how. As soon as that step will become progressively more frequent, adoption of innovative approaches like the one described here is likely to require far less effort than is the case at present.

\section{AUTHOR CONTRIBUTIONS}

The author confirms being the sole contributor of this work and has approved it for publication.

\section{ACKNOWLEDGMENTS}

The reflection presented in this opinion piece owes a tremendous amount to the foresight of André Lacroix, my junior-year high-school teacher at the Collège Cardinal Mercier in Brainel'Alleud (Belgium) in 1974, and to the White Fathers Guy Pinard (assassinated in Rwanda in 1997) and André Douillard. They have all my gratitude.

Ketcham, C. (2012). Monopoly is Theft: The Antimonopolist History of the World's Most Popular Board Game. Browsings, The Harper's blog. Harper's Magazine. Available online at: https://harpers. org/blog/2012/10/monopoly-is-theft/?single=1 (Accessed December 18, 2016).

Lagemann, E. C., and Lewis, H. (eds) (2011). What is College for? The Public Purpose of Higher Education. New York, NY: Teachers College Press.

Lambrichs, L. (2009). Linvention Sociale - A l'écoute de Bertrand Schwartz. Paris: Philippe Rey.

Peters, W. (1987). A Class Divided: Then and Now. New Haven, CT: Yale University Press.

Pilon, M. (2015). The Monopolists: Obsession, Fury, and the Scandal Behind the World's Favorite Board Game. London: Bloomsbury.

Roth, M. S. (2017). What is College for? (Hint: It's not just about getting in.) The Washington Post.

Saavedra, A. R., and Opfer, V. D. (2012). Learning $21^{\text {st }}$ century skills requires $21^{\text {st }}$ century teaching. Phi Delta Kappan 94, 8-13. doi: $10.1177 / 003172171209400203$

Conflict of Interest Statement: The author declares that the research was conducted in the absence of any commercial or financial relationships that could be construed as a potential conflict of interest.

Copyright (C) 2019 Baveye. This is an open-access article distributed under the terms of the Creative Commons Attribution License (CC BY). The use, distribution or reproduction in other forums is permitted, provided the original author(s) and the copyright owner(s) are credited and that the original publication in this journal is cited, in accordance with accepted academic practice. No use, distribution or reproduction is permitted which does not comply with these terms. 